SULUH Jurnal Bimbingan Konseling, April 2017, Volume 3 Nomor 1 (12-18)

http://jurnal.umpalangkaraya.ac.id/ejurnal/suluh

\title{
LAYANAN KONSELING KELOMPOK SOLUTION FOCUSED BRIEF THERAPY (SFBT) UNTUK MENGURANGI PERILAKU CYBER BULLYING PADA PESERTA DIDIK KELAS VIII-7 DI SMPN-3 PALANGKA RAYA
}

\author{
Oleh \\ Aminudin, Karyanti
}

\begin{abstract}
ABSTRAK
Tujuan penelitian ini untuk mengetahui efektifitas layanan konseling kelompok SFBT dalam mengurangi perilaku cyber bullying peserta didik kelas VIII-7 di SMPN-3 Palangka Raya. Populasi dalam penelitian ini berjumlah 35 orang peserta didik. Jumlah sampel penelitian terdiri dari 8 orang peserta didik. Pengambilan sampel ditentukan dengan teknik Purposive Sampling. Teknik pengumpulan data menggunakan observasi, wawancara, dan skala perilaku cyber bullying. Metode yang digunakan adalah preeksperimen, teknik pengumpulan data menggunakan rumus Paired-Sample T Test atau lebih dikenal dengan Pre-Post Design adalah analisis dengan melibatkan dua pengukuran pada subjek yang sama terhadap suatu pengaruh atau perlakuan tertentu.

Hasil uji Paired-Sample T Test, menunjukkan bahwa perilaku cyber bullying mengalami penurunan rata-rata awal 191.50 menjadi 115.50, dengan jumblah rata-rata penurunan sebesar 76. Artinya "Layanan Konseling Kelompok Solution Focused Brief Therapy (SFBT) dapat Menurunkan Perilaku Cyber Bullying pada Peserta Didik Kelas VIII-7 di SMPN-3 Palangka Raya Tahun Ajaran 2015/2016". Hasil analisis menunjukan bahwa kedelapan peserta didik pada subjek penelitian mengalami penurunan tingkat perilaku cyber bullying sebelum dilakukan intervensi dan sesudah dilakukan intervensi.
\end{abstract}

(C) Universitas Muhammadiyah Palangkaraya

Kata Kunci: Cyber Bullying, Konseling kelompok Solution Focused Brief Therapy SFBT.

\section{PENDAHULUAN}

Peserta didik mampu mengembangkan potensi diri untuk mencapai tugas-tugas perkembangannya menyangkut aspek emosi dan moral yang ada di dalam diri peserta didik tersebut, selain itu peserta didik dipandang sebagai seorang individu yang sedang berkembang ke arah kematangan untuk mencapai kematangan tersebut peserta didik memerlukan bimbingan, karena peserta didik masih belum memiliki pengalaman dan wawasan tentang dirinya dan juga lingkungannya.

Masa remaja juga merupakan masa yang penuh dengan dinamika dimana pada masa-masa tersebut terjadi perkembangan dan perubahan pada diri remaja baik itu perubahan biologis maupun kognitif karena pada periode ini merupakan masa transisi dari anak- 
anak menuju dewasa, dimana dimasa inilah peserta didik cenderung beresiko melakukan tindakan diluar rasional dikarenakan pada rentang usia 11-15 tahun peserta didik mengalami permasalahan emosional yang meledakledak yaitu berupa tekanan rasa ingin tahu yang tinggi, ingin mencoba dan rasa penasaran yang berlebihan, karena banyaknya perubahan yang timbul dari masa-masa sebelumnya sehingga menyebabkan timbulnya perilaku menyimpang yaitu kenakalan dan kekerasan.

Hurlock (2014) goncangangoncangan yang terjadi pada masa-masa remaja berhubungan dengan perubahan emosional. Emosi yang kurang matang pada remaja terlihat pada permasalahan remaja yang melakukan perilaku menyimpang seperti perilaku kekerasan perilaku kekerasan yang dilakukan remaja dikenal dengan istilah bullying. Roland (2006: 8) bullying adalah kekerasan mental dan juga fisik yaitu intimidasi, menggertak yang dilakukan oleh individu atau kelompok secara berulang dengan hubungan kekuasaan yang tidak setara antara pelaku dan korban. Priyatna dalam Dyastuti (2012) bullying adalah tindakan yang disengaja oleh si pelaku pada korbannya, bukan sebuah kelalaian memang betul-betul disengaja. Afriana, dkk (2014: 2) bullying merupakan suatu bentuk perilaku agresif yang diwujudkan dengan perlakuan secara tidak sopan dan penggunaan kekerasan atau paksaan untuk mempengaruhi orang lain, yang dilakukan secara berulang atau berpotensi untuk terulang, dan melibatkan ketidak seimbangan kekuatan

Perkembangan peserta didik juga merupakan masa dimana peserta didik menemukan jati diri, pencarian tersebut direfleksikan melalui aktivitas berkelompok dan menonjolkan keegoan, peserta didik pada umumnya masih berusia remaja memiliki kecenderungan untuk melakukan halhal diluar dugaan yang kemungkinan dapat merugikan diri sendiri dan orang lain, salah satu tindakan tersebut adalah melakukan kekerasan.

Peserta didik begitu banyak melakukan kekerasan, sehingga muncul kekhawatiran bahwa kekerasan dapat dianggap sebagai suatu hal yang normal dan wajar dalam masyarakat, kenyataan di lapangan masih banyak terjadi kekerasan pada anak terutama di lingkungan sekolah. Teror berupa kekerasan fisik atau mental, pengucilan, intimidasi, dan perpeloncoan yang sering terjadi sebenarnya adalah contoh klasik dari apa yang disebut dengan bullying.

Menurut Olweus (dalam Karyanti, dkk (2015:116) mengidentifikasikan ada dua subtipe bullying, yaitu direct bullying, misalnya penyerangan secara fisik dan indirect bullying, seperti pengucilan secara sosial. Bullying disebut sebagai sub tipe dari perilaku agresif karena di dalam melibatkan agresi atau serangan. Menurut Kim (dalam Utami, 2014:2) bullying dapat dilakukan secara verbal, psikologis dan fisik. Namun sekarang ini, bullying tidak hanya terjadi dikehidupan nyata saja, bullying sekarang juga terjadi di dunia internet atau cyber. Bullying yang 
terjadi di internet atau cyber dinamakan dengan cyber bullying. Menurut Ayunintgyas, dkk (2013:7) "pembajakkan akun pribadi seseorang, penyebaran berita bohong atau fitnah juga termasuk perilaku cyber bullying

Menurut Roland (2006:9) berpendapat bahwa mobile phone bullying atau juga disebut cyber bullying merupakan Bullying yang dilakukan melalui ponsel, melalui percakapan, pesan teks dan foto adalah masalah yang relatif baru, karena meluasnya penggunaan ponsel. Cyber bullying sama dengan bullying yang terjadi pada umumnya, yaitu sama-sama mengintimidasi ataupun mengganggu orang yang lemah, cyber bullying ini banyak terjadi di media sosial. Kejadian ini dipicu ketika seorang anak atau remaja diejek, dihina, diintimidasi, atau dipermalukan oleh anak atau remaja lain melalui media internet, teknologi digital atau telepon seluler. Motivasi seseorang melakukan cyber bullying hampir sama dengan bullying. Menurut Syam (2015:78) ada dua faktor seseorang melakukan tindakan cyber bullying faktor yang bersumber dari dalam diri pelaku (Internal) dan faktor yang berasal dari luar (external).

Menurut Rahayu (2011:7) dampak dari cyber bullying untuk para korban tidak berhenti sampai pada tahap depresi saja, melainkan sudah sampai pada tindakan yang lebih ekstrim yaitu bunuh diri. Menurut Psikolog anak Vera Itabiliana Hadiwidjojo (Kompas, 2015:11). (dalam Maya, 2015:449) tindakan cyber bullying sering dialami oleh anak yang secara mental terlihat berbeda. Mereka akan cenderung terlihat pendiam, pemalu, dan akan tertutup. Suminar (2014:2) korban cyber bullying merasa tidak senang pergi ke sekolah, meskipun mereka senang belajar di sekolah namun mereka merasa tidak aman dan merasa terisolasi.

Berdasarkan hasil observasi pada hari senin, tanggal 10 bulan agustus tahun 2015 di SMPN-3 Palangka Raya kelas VIII-7, terdapat peserta didik yang cenderung melakukan tindakan perilaku cyber bullying yaitu, peserta didik yang cenderung menyebar berita tidak benar melalui akun media sosial yaitu dengan (Broadcast), peserta didik yang cenderung melakukan tindakan perilaku cyber bullying mengganti foto profil, peserta didik yang cenderung melakukan tindakan perilaku cyber bullying mengganti nama profil di media sosial dan membuat status dengan kata-kata kotor di akun media sosial. Sehingga membuat peserta didik yang menjadi korban merasa malu marah karena dilihat oleh teman-teman pengguna media sosial lain. Peserta didik melakukan ini tidak hanya sekali tetapi sudah beberapa kali dan tidak hanya dilakukan oleh satu peserta didik tetapi ada beberapa peserta didik lain yang sering melakukan hal yang sama. Berdasarkan wawancara dengan guru BK terdapat peserta didik yang tidak mau kesekolah karna menjadi korban cyber bullying oleh temannya.

Fenomena yang terjadi diantara peserta didik perlu diatasi dengan alternatif bantuan layanan BK yang bisa mengakomodir sejumlah peserta didik tersebut secara bersama-sama agar terpecahnya suatu masalah yang timbul 
dari tindakan perilaku cyber bullying yang terjadi salah satu upaya untuk mengurangi perilaku cyber bullying di atas adalah dengan melakukan Layanan Konseling Kelompok. Rusmana (2009:3) layanan konseling kelompok merupakan suatu upaya remedial saat membahas topik atau isu-isu seputar hal-hal yang mengganggu atau menghambat proses belajar dan perkembangan kelompok siswa tertentu.

Kemendikbud (2014:127) layanan konseling kelompok adalah layanan bimbingan dan konseling yang membantu peserta didik dalam pembahasan dan pengentasan masalah yang dialami sesuai tuntutan melalui dinamika kelompok. Gazda 1978 (dalam Astuti, 2012:3) konseling kelompok adalah suatu proses antar pribadi yang dinamis, yang terpusat pada pemikiran dan perilaku yang disadari.

Gibson \& Mitchell (2011:282) tujuan konseling kelompok adalah memenuhi kebutuhan dan menyediakan pengalaman nilai bagi setiap anggotanya secara individu yang menjadi bagian kelompok tersebut. Menurut Afriana, dkk (2014:6) Dalam konseling kelompok dibahas masalah pribadi yang dialami masing-masing anggota kelompok melalui suasana dinamika kelompok. Menurut Sanyata (2010:3) proses konseling kelompok paling tidak melalui tahap-tahap berupa; tahap awal dalam kelompok, tahap transisi, tahap pelaksanaan dan tahap akhir dari proses kelompok

Menurut Palmer (2010) layanan konseling kelompok solution focused brief therapy SFBT merupakan bentuk konseling singkat yang dibangun diatas kekuatan konseli dengan membantunya memunculkan dan mengkonstruksikan solusi pada problem yang dihadapinya. Pendekatan konseling yang mempertahankan aspek keefektifan dan efesiensi dalam mewujudkan perubahan merupakan pendekatan yang berangkat dari landasan filosofi pasca modern dan konstruktivisme sosial. Charlesworth dan Jackson (dalam Sari, 2014:7) Konseling kelompok solution focused brief therapy SFBT cocok untuk setting sekolah karena efektif menciptakan perubahan pada diri konseli selama sesi konseling dengan waktu yang lebih singkat. Berdasarkan masalah dan juga pendapat ahli tersebut maka peneliti ingin mengembangkan sebuah strategi layanan konseling untuk melakukan penelitian untuk mengurangi perilaku cyber bullying, alternatif penyelesaian masalah cyber bullying yang peneliti tawarkan bukanlah solusi total, namun hanya sebagai solusi awal. Peneliti melaksanakan penelitian untuk mengurangi perilaku cyber bullying dengan judul: "Layanan Konseling Kelompok Solution Focused Brief Therapy (SFBT) untuk Mengurangi Perilaku Cyber Bullying pada Peserta Didik.

\section{METODE PENELITIAN}

Metode penelitian yang digunakan dalam penelitian ini adalah metode preeksperimen. Creswell (2010:241) rancangan penelitian mencakup satu kelompok yang diobservasi pada tahap pre-test yang kemudian dilanjutkan dengan treatment dan post-test. Arikunto (2013:3) penelitian 
eksperimen adalah suatu cara untuk mencari sebab akibat (Hubungan kausal) antara dua faktor yang sengaja ditimbulkan oleh peneliti dengan mengurangi atau menyisihkan faktorfaktor lain yang bisa menggangu.

\section{Gambar 1}

Desain Penelitian

Pre-test Treatment Post-tes $\mathrm{O} 1 \longrightarrow \mathrm{X} \longrightarrow \mathrm{O} 2$

Sugiyono (2013:109)

Subjek penelitian dalam penelitian ini adalah peserta didik kelas VIII-7 di SMPN-3 Palangka Raya yang berjumlah 35 orang peserta didik. Peneliti mengambil 8 orang peserta didik yang teridentifikasi melakukan perilaku cyber bullying untuk dijadikan sebagai subjek penelitian. Teknik pengambilan subjek pada penelitian ini menggunakan purposive sampling. Purposive sampling adalah teknik penentuan sampel dengan pertimbangan tertentu (Sugiyono, 2014:156).

Instumen yang digunakan dalam penelitian ini terdiri dari bahan perlakuan berupa buku panduan, skala cyber bullying dan rubrik observasi sebelum instumen itu digunakan dalam penelitian terlebih dahulu dilakukan uji validitas konstruksi (validitas ahli).

\section{HASIL DAN PEMBAHASAN}

hasil pengukuran tingkat perilaku cyber bullying dengan menggunakan skala perilaku cyber bullying saat pretes dan post-test pada subjek penelitian digambarkan dalam gambar diagram di bawah ini

Gambar 2

Hasil Pre-Test dan Post-Test Pada

Subjek Penelitian

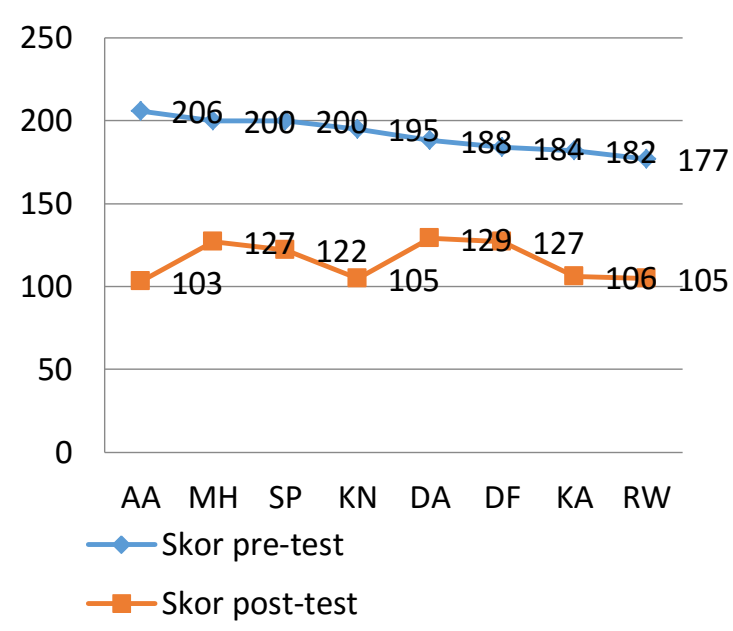

Hasil pre-test subjek penelitian menunjukkan bahwa seluruh anggota kelompok yang terdiri dari 8 peserta didik yang teridentifikasi sebagai perilaku cyber bullying berada pada kategori sedang dengan rentang skor 206 sampai 177 setelah diketahui skor perilaku cyber bullying pada saat pretest, semua anggota kelompok diberikan intervensi berupa konseling kelompok SFBT untuk mengurangi perilaku cyber bullying anggota kelompok. Intervensi layanan konseling kelompok SFBT dilakukan sebanyak enam kali pertemuan. Setelah intervensi diberikan, terjadi perubahan tingkat perilaku cyber bullying yang ditunjukkan oleh anggota subjek penelitian. Perubahan tingkat perilaku cyber bullying dapat diketahui melalui pengukuran yang dilakukan menggunakan skala perilaku cyber 
bullying dan dilakukan setelah proses pemberian intervensi (post-test).

Hasil post-test menunjukkan semua anggota kelompok mengalami penurunan tingkat perilaku cyber bullying dengan perilaku cyber bullying kategori rendah dengan rentang skor 103 sampai 129.

Pengujian hipotesis dilakukan dengan menggunakan Sample T Test, Paired-Sample T Test atau lebih dikenal dengan Pre-Post Design. Hasil analisis menunjukan bahwa perilaku cyber bullying mengalami penurunan rata-rata awal 191.50 menjadi 115.50, dengan jumblah rata-rata penurunan sebesar 76 .

\section{KESIMPULAN}

Berdasarkan hasil analisis dan pembahasan di atas, maka dapat disimpulkan bahwa Layanan Konseling Kelompok Solution Focused Brief Therapy (SFBT) dapat Menurunkan Perilaku Cyber Bullying pada Peserta Didik di Kelas VIII-7 SMPN-3 Palngka Raya. Hal tersebut didasarkan pada hasil uji Paired-Sample $\mathrm{T}$ Test, menunjukkan bahwa perilaku cyber bullying mengalami penurunan rata-rata awal 191.50 menjadi 115.50 , dengan jumblah rata-rata penurunan sebesar 76 . Artinya "Layanan Konseling Kelompok Solution Focused Brief Therapy (SFBT) dapat Menurunkan Perilaku Cyber Bullying pada Peserta Didik Kelas VIII7 di SMPN-3 Palangka Raya Tahun Ajaran 2015/2016". Hasil analisis menunjukan bahwa kedelapan peserta didik pada subjek penelitian mengalami penurunan tingkat perilaku cyber bullying sebelum dilakukan intervensi dan sesudah dilakukan intervensi.

\section{DAFTAR PUSTAKA}

Arikunto, S. 2013. Prosedur Penelitian Suatu Pendekatan Praktik. Jakarta: Rineka Cipta.

Azwar, S. 2015. Penyusunan Skala Psikologi. Yogyakarta: Pustaka Pelajar.

Astuti, B. 2012. Modul Konseling Individual.Program Studi Bimbingan dan Konseling. Yogyakarta: Fakultas Ilmu Pendidikana UNY

Afriana, D. Yusmansyah, D. \& Utaminingsih. 2014.Upaya Mengurangi Perilaku Bullying Di Sekolah Dengan Menggunakan Layanan Konseling Kelompok. Jurnal BK UNILA. http://jurnal.fkip.unila.ac.id

Ayunintgyas, D A. Sarkadi \& Timoera D A. 2013. Efektivitas UndangUndang Informasi Dan Transaksi Elektronik Dalam Meredam Perilaku

Cyberbullying.Universitas Negeri Jakarta.Jurnal PpknISSN: 23375205 Volume 1, Nomor 2, Tahun 2013.

Creswell, J W. 2010. Research Design Pendekatan Kualititaif, Kuantitatif, dan Mixed. (Terjemahan Achmad Fawaid). Yogyakarta: Pustaka Pelajar.

Corey, G. 2012. Theory and Practice of Counseling and Psychotherapy ( $8^{\text {th }} E d$.). Belmont, CA: Brook/Cole.

Dyastuti, S. 2012. Mengatasi Perilaku Agresif Pelaku Bullying Melalui Pendekatan Konseling Gestalt Teknik Kursi Kosong.Indonesian 
Journal Of Guidance and Counseling Theory and Apllication. Universitas Negeri Semarang Indonesia. ISSN 22526374

Gibson, R L \& Mitchell M, H. 2011. Bimbingan dan konseling. Jakarta: Pustaka Belajar Edisi Indonesia.

Hurlock, E B. 2014. Piskologi Perkembangan Suatu Pendekatan Sepanjang Rentang Kehidupan. Edisi Kelima Yoyakarta: Erlangga.

Kemdikbud. 2014. Materi Pelatihan Implementasi Kurikulum 2013. Jakarta: KEMDIKBUD

Karyanti, Atmoko, A dan Hitipeuw, I. 2015. Keefektifan Pelatihan Keterampilan Arsertif untuk Meningkatkan Perilaku Arsertif Siwa Korban Bullying di SMA. Malang.

Juornal.um.ac.id/index.php/jph .

Maya, N. 2015. Fenomena Cyberbullying Di Kalangan Pelajar.Program Studi Ilmu Komunikasi, FISIP, Universitas Tribhuwana Tunggadewi, Malang. Jurnal Ilmu Sosial dan Ilmu Politik ISSN.2442-6962 Vol. 4, No. 3.

Palmer, S. 2010. Konseling dan Psikoterapi. Yogyakarta: Pustaka Pelajar.

Rusmana, N. 2009. Metode Penelitian Pendidikan Pendekatan Kuantitatif, Kualitatif, Amplikasi. Bandung: Risqi Press.

Roland, E. 2006. Teachers Gude To The Zero Anti Bullying Centre For Behavioral Research
Programmen. University Of Skavanger: Norway.

Rahayu, F S. 2011. Dampak Negatif Penggunaan Teknologi Informasi dalam Bentuk Cyberbullying di Kalangan Anak dan Remaja.Jurnal UAJY. http://ejournal.uajy.ac.id/

Sugiyono. 2014. Metode Penelitian Manajemen, Bandung: Alfabeta.

Sugiyono. 2013. Metode Penelitian Pendidikan, Bandung: Alfabeta.

Sanyata, S. 2010. Teknik Dan Srategi Konseling Kelompok. Diterbitkan pada Jurnal Paradigma No. 09 Th. V, Januari 2010 ISSN 1907-297X/.

Sari, D K. 2014. Keefektivan konseling kelompok singkat berfokus solusi untuk mengurangi perilaku agresif siswa Sma.Universitas Negeri Malang Pascasarjana Program Studi Bimbingan dan Konseling.Tesis.

Suminar, D R \& Danirmala P. 2014. Perbedaan Perilaku Cyberbullying Ditinjau Dari Persepsi Siswa Terhadap Iklim Sekolah Di Smk Negeri 8 Surabaya.Fakultas Psikologi Universitas Airlangga Surabaya.ISSN 2301-7082 Volume No. 3.

Syam, A A. 2015. Bagian Hukum Pidana Fakultas Hukum Universitas Hasanuddin Makassar.http://repository.unhas. ac.id/

Utami, Y C. 2014. Cyberbullying Di Kalangan Remaja, Studi Tentang Korban Cyberbullying Di Kalangan Remaja Di Surabaya. 
Universitas Airlangga.

http://www.journal.unair.ac.id/ 